Jurnal Bimbingan Konseling
$10(1)(2021): 42-48$
UNNES

\title{
The Effectiveness of Group Counseling with Sfbc And Mindfulness Training Group Approaches to Reduce the Technostress of Students Who Use Smartphone
}

\author{
Ahmad Munir $^{1 凶}$, Sugiyo Sugiyo $^{2}$, Mulawarman Mulawarman $^{2}$ \\ ${ }^{1 .}$ SMK Negeri 1 Warungasem, Batang, Indonesia \\ 2. Universitas Negeri Semarang, Indonesia
}

\begin{tabular}{l}
\hline Article Info \\
\hline History Articles \\
Received: \\
23 January 2021 \\
Accepted: \\
27 February2021 \\
Published: \\
30 April 2021 \\
\hline Keywords: \\
Mindfulness; SFBC; \\
Smartphone; \\
Technostress \\
\hline
\end{tabular}

\begin{abstract}
Smartphone presence in today's era truly advantages students in both learning process and personal business. However, when there is no good time management of smartphone usage, students may experience technostress. Regarding this issue, this study strived to examine the effectiveness of group counseling with SFBC and mindfulness training group approaches to reduce the technostress of students who use smartphone. In its implementation, there were 14 students chosen using random assignment as the samples and divided into two groups with each group consisted of 7 students. For the method, this study used experimental method with randomized pretest-posttest comparison group design. Students' technostress data were collected using technostress scale and analyzed through Wilcoxon Sign Rank Test and Mann Whitney. It was found that: 1) the group counseling with SFBC approach successfully reduced the students' technostress in the SFBC experimental group. 2) Mindfulness training group made it to reduce the students' technostress in mindfulness training group experimental group. 3) the intervention in the SFCB experimental group appeared to be more effective to reduce the technostress of students who use smartphone compared to the mindfulness training group. Thus, it is recommended to apply the group counseling with SFBC approach to reduce the technostress of students who use smartphone.
\end{abstract}

$\bowtie$ Correspondence address:
Wonosari VillageNA. 05 CA. 03 Bawan, Batang Jawa Tengah,
(51274)

p-ISSN 2252-6889

e-ISSN 2502-4450

E-mail: wonosaribawang16@gmail.com 


\section{INTRODUCTION}

Adolescents are attracted to try new things and learn new knowledge. One of ways to access those things is via the internet. As Issa \& Isaias, 2016; Ozkan \& Solmaz (2015) mention adolescent's lives are strongly related to all the sophistication and modernization of technology. However, the compulsive use of it will affect changes in their social attitudes and behavior as well as affect the accomplishment of developmental tasks (Arifin, 2015).

Uncontrolled smartphone use will cause technostress (Nisak, I.A., 2020). Technostress is caused by the uncontrollable use of technology which further can drain its users' energy and thoughts and even give negative impacts on the user's physical and psychological condition (Tarafdar, 2007). Technostress phenomenon is serious that according to Ibrahim, Bakar, and nor (Shu, Tu, and Wang, 2011) students who suffer from this condition will have an impact on the inability to concentrate, increase in emotion or anger and lose control.

Based on the above elaboration, the researchers defined indicators or symptoms of smartphone addictive usage and determined its effects on the students of SMK Negeri 1 Warungasem in Batang Regency during the preliminary study. It was found 6 students admitted using smartphone and internet almost every day both at school and outside the school. In one day, those students approximately used smartphone for 5 to 6 hours. In addition, two students said that the requirement to use technology as a learning medium caused them to feel forced since they were demanded to learn faster and burdened due to the constant connection with technology, but at the same time they felt no changes in their skills because of the learning force. A student was found to feel anxious and fear of failure by virtue of lack technology mastery since he was forced to keep developing and updating his skills. For more, three students mentioned they were bored when they encountered with computer hardware problems and prohibition on the late assignment submission.
According to the results of the preliminary study, it can be seen that there is a relationship between smartphone and technostress as stated in a study by Tarafdar (2007) that the compulsive use of technology can cause technostress. Kim and Shin (2016) argues the same idea smartphone has a positive relationship with technostress.

Various studies carried out to investigate and explore the use of smartphone mainly focused on factors, smartphone user's behavior, and the effects of smartphone on its users' behavior, while this study was conducted to implement some approaches in guidance and counseling field to determine an appropriate intervention to reduce technostress symptoms.

The approaches used in this study were SFBC and Mindfulness training group. The use of these approaches was based on Fox's ideas (2014), namely the appropriate intervention to deal with negative effects of information and technology is the one which can solve physical and mental disorders. Ferziani, et al (2018) supports this idea in which their study concludes students who suffer from information and technology syndrome becomes individuals who are short on time and impatient with others and themselves.

Of all the above studies, the researchers believed that the suitable approach for reducing students' technostress is the one which has a short period of intervention. That was why Solution-Focused Brief Counseling (SFBC) was considered as the proper approach. It is supported by Mulawarman (2014) who argues SFBC is suitable to be applied in school settings since it focuses on students' strengths rather than weaknesses, has short period of time to be implemented, emphasizes solutions, and goal achievement. Similarly, mindfulness was also considered suitable. Nurhaeda (2019) explains mindfulness training with slow deep breathing is a valuable relaxation technique, quite easy to learn, fast, easy to do and can be practiced by anyone, anywhere.

Concerning the previous explanation of the phenomenon, the reduction of negative effects of smartphone, and proofs of the 
effectiveness of group counseling with SFBC and mindfulness training group approaches, the researchers assumed that the group counseling with SFBC and mindfulness training group which originally come from eastern culture and act as psychological constructs have some influence on smartphone users' technostress. Hence, the assumption could be validated in scientific research procedures with hope that the findings of this study will contribute some intervention alternatives to reduce technostress.

The aim of this study was to analyze the effectiveness level of the group counseling with SFBC and mindfulness training group approaches to reduce the technostress of students who use martphone in SMK Negeri 1 Warungasem in Batang Regency. It was expected that this study could determine the suitable and effective intervention to reduce technostress.

\section{METHODS}

This study was done to the students of SMK Negeri 1 Warungasem in Batang Regency who experienced technostress amounted to 14 students. They were grouped into two with 7 students in each. In details, the SFBC group had 7 students consisting of 3 male students and 4 female students whose age ranged from 16 to 18 years, and the mindfulness training group members were 7 including 5 male students and 2 female students whose age ranged from 17 to 18 years.

To collect the data, the reserachers used a psychological scale or technostress instrument based on Tarafdar, et al. theory (2007), namely techno overload (technology burden), techno invasion (technology invasion), techno insecurity (technological complexity), techno complexity (technology anxiety), and techno uncertainty consisting of 23 items with 4 scaling levels $(1=$ very appropriate, $4=$ very inappropriate). Based on Cronbach Alpha test this scale has a reliability value of 0.73 .

In terms of approach, this study was quantitative with the experimental design of Randomized Pretest-Posttest Comparison Group. Through this design, the researchers performed several procedures. First, the provision of pretest focusing on students' technostress aiming at determining students' technostress whether high, fair, or low. Second, random assignment was applied to the subjects to place them into two experimental groups, namely the group counseling with SFBC approach and the group counseling with mindfulness training group approach. The SFBC group received counseling service for five sessions with a time allocation of 2 times 45 minutes for each. For the time being, the mindfulness training group got four sessions with a time allocation of 2 times 45 minutes for each. Third, once the interventions were done, each group member was asked to fill out technostress scale again.

For data analysis, this study used Wilcoxon Sign Rank Test analysis and Mann Whitney test.

\section{RESULTS AND DISCUSSION}

In this study, quantitative descriptive analysis was employed to calculate mean and standard deviation. It was focused on examining the level of students' technostress before (pretest) and after the intervention was given. 
Table 1. Students' Technostress Category in Pretest and Posttest

\begin{tabular}{|c|c|c|c|c|c|c|c|}
\hline \multirow{2}{*}{ Group } & \multirow{2}{*}{$\mathrm{N}$} & \multicolumn{3}{|c|}{ Pre-Test } & \multicolumn{3}{|c|}{ Post-Test } \\
\hline & & $\mathrm{M}$ & SD & Category & $\mathrm{M}$ & SD & Category \\
\hline KK SFBC & 7 & 72 & 6 & High & 63 & 3 & Fair \\
\hline MTG & 7 & 74 & 4 & High & 64 & 6 & Fair \\
\hline Total & 14 & 146 & 10 & High & 127 & 19 & Fair \\
\hline & & & 11 & & & & \\
\hline
\end{tabular}

Information:

$\mathrm{M}=$ Mean

KK SFBC = SFBC Group Counseling

From the results of pretest in table 1 , the level of students' technostress was varied in each group, namely the group counseling with SFBC approach was in the high category of technostress prior to the intervention $(\mathrm{M}=72$; $\mathrm{SD}=6)$, while its posttest showed reduction and dropped to medium category $(M=63 ; \mathrm{SD}=2)$. In the mindfulness training group, the results of the pretest on technostress showed high category $(\mathrm{M}=74 ; \mathrm{SD}=4)$, while in the posttest they were in the medium category $(\mathrm{M}=64 ; \mathrm{SD}=6)$.

The above elaboration is in line with the results of the previous studies that there is a

$$
\begin{aligned}
& \text { SD = Standar Deviasi } \\
& \text { MTG = Mindfulness Training Group }
\end{aligned}
$$

relationship between technostress and smartphone (Fox, 2014). In his study, he mentions smartphone causes more sensitive response to rpressure than other kinds of technological devices and contributes to general cause of technostress increase. Similarly, Lee (2014) who highlighted the negative effects of smartphone concludes the compulsive use of smartphone is significantly related to psychological attitudes. He then maps the differences in the effects caused by smartphone and conventional phone (Lee, Chang, Cheng, and Lin, 2016).

Table 2. The Level of Technostress in KK SFBC and MTG

\begin{tabular}{lllll}
\hline \multirow{2}{*}{ Group } & Median & \multirow{2}{*}{$Z$} & \\
\cline { 2 - 4 } & Pre-Test & Post-Test & -2.37 & $<0,05$ \\
\hline KK SFBC & 4 & 0 & -2.37 & $<0,05$ \\
MTG & 7 & 1 & & \\
\hline$z 2$ & & 0,84 & \\
$P$ & & $>0,05$ & \\
\hline
\end{tabular}
Ket:
$z 1=$ wilcoxon signed rank test,
$z 2=$ uji mann whitney,
$P=$ Significance,
KK SFBC $=$ SFBC Group Counseling, MTG = Mindfulness training group

According to the results of Wilcoxon signed rank test in table 2, the group counseling with SFBC was effective to reduce technostress $(z 1=-2.37, p<0.05)$. In the same way, mindfulness training group was also effective to reduce this disorder $(\mathrm{z} 1=-2.37, \mathrm{p}<0.05)$. The overall effectiveness of both techniques was at the same level $(z 2=-0.84, p>0.05)$.

As presented in table 2, the students who joined the group counseling with SFBC approach and mindfulness training group experienced technostress reduction. It was because students who joined the experimental group felt that they have got some hopes and were empowered by those hopes to influence their environment and deserve better future to achieve what they desire (Erford, 2016). These ideas are in accordance with Fox (2014) that a suitable intervention for technology negative 
effects is the one which can give relaxation and cope with physical and mental disorder.

The findings underpin the previous studies of the effectiveness of group counseling with SFBC approach as an intervention for various students' problems. It is like a study by Hendar, Awalya, and Sunawan (2019) which discusses the effectiveness of the group counseling with SFBC approach to improve student's academic resilience and self-efficacy and Rusandi, Sugiharto, \&Sunawan's research (2019) entitled the effectiveness of group counseling with SFBC approach to enhance student's skills.

In terms of mindfulness approach, this study enriches the findings of the previous studies with the topic of the effectiveness of mindful approach such as a study by Costello \&Lawlera, (2014); Kar, (2014) about mindfulness to reduce stress levels; Malinowski \& Lim (2015) on the implementation of mindfulness to get positive effects on work engagement by improving positive influence, hope, and optimism; Prakash et al (2015) about emotion regulation which mediates the relationship between mindfulness and stress; Leland's study (2015) on the use mindfulness to help students become more successful learners, and a study by Susanti, Wibowo and Mulawarman (2019) which proves the effectiveness of mindfulness to reduce school fatigue.

The implementation of counseling in this study was for assisting students to be optimistic in realizing that every human is healthy and competent. Having an ability in making solutions to improve life quality optimally is able to bring back someone who is lost or unconscious about abilities he has (McLeod J, 2010: 167). Therefore, being able to reduce technostress shortly, having a counseling that focuses on solutions, and goal achievement (Mulawarman, 2014) with slow breathing that is easy to learn, fast, easy to do (Nurhaeda, 2019) has been proved to be effective in reducing technostress.

The aforementioned findings are in association with a theory by Schmit\& Lenz
(2016) which states that SFBC approach is effective to treat symptoms of internalization disorders in adolescents. Also, it is relevant to the opinion of Shakarami, Davarniya \& Zahrakar (2014) state that SFBC approach is effective to reduce stress. Correspondingly, with regard of mindfulness, the findings have fulfilled the process of non-judgemental and acceptance improvement as well as improved the awareness and attention to the cognitive, emotional, and somatic experience process (Kabat-Zinn, 2006: 145). Moreover, Erford's (2016) mentions that mindfulness approach is based on the belief that by being able to control one's breathing, a person is considered to be able to control his life energy.

Furthermore, the findings above are relevant to the statement of Mulawarman (2019) that in counseling process it is better for counselors to empower the "strength" of the counselees' culture so that they can progress more quickly because they feel that "counseling is fun". This idea corresponds to Awalya's(2015) that the ideal professionalism of counselors is to provide guidance and counseling services in schools by optimizing culture-based competency.

\section{CONCLUSION}

By referring to the findings, the pretest results showed the technostress level of the students of SMK Negeri 5 Warungasem in Batang Regency in both experimental and control groups were high. However, once the group counseling with SFBC approach was implemented, the technostress level of the SFBC group got reduced evidence by the results of hypothesis testing through wilcoxon analysis. It means that the group counseling with SFBC approach is effective to reduce the technostress level of students who use smartphone. Accordingly, based on the hypothesis testing using Wilcoxon analysis the mindfulness training group successfully reduces the technostress of the mindfulness training experimental group members. It indicates that the mindfulness training group is effective to reduce the technostress level of students who use 
smartphone. Even though both techniques are able to reduce the technostress, there are some differences found in the data of pretest and posttest analyzed using Mann Whitney test.

The future researchers are suggested to add other variables as the independent variable or use moderating variable to reveal variables strengthening and influencing the dependent variable. Besides, counselors are required to improve their counseling competency to improve the effectiveness of treatments in handling similar cases.

\section{REFRENCES}

Arifin, Z. (2015). Perilaku Remaja Pengguna Gadget; Analisis Teori Sosiologi Pendidikan. Tribakti: Jurnal Pemikiran Keislaman, 26 (2), 287-316.

Awalya (2015). Upaya Pengembangan Pelatihan Peningkatkan Kompetensi Berbasis Budaya Guru BK di sekolah. Prosiding multikultural.

https://www.academia.edu.

Behzad Behbahani, A., Lages, W. S., \& Kelliher, A. (2019, March). A Multisensory Design Probe: An Approach for Reducing Technostress. In Proceedings of the Thirteenth International Conference on Tangible, Embedded, and Embodied Interaction. 459-466. Doi: $10.1145 / 3294109.3300992$

CostelloElizabeth Lawlera\&LawleraMargaret (2014). An Exploratory Study of the Effects of Mindfulness on Perceived Levels of Stress Among Schoolchildren From Lower Socioeconomic Backgrounds.International Journal of Emotional Education, 6 (2): 21-39. Doi: EJ1085614.

Erford, B., 2016. 40 Techniques a Counselor Should Master. Second Edition. Yogyakarta: Student Library.

Ferziani, A., Rajagukguk, R. O., \&Analya, P. (2018). Types of Technostress on Employees of IT Consulting Company. In 2018". International Conference on Orange
Technologies (ICOT): 1-5. IEEE. Doi: 10.1109/ICOT.2018.8705838

Fox, O. J. (2014). What Impact do Smartphones have on Technostress? Discovery, Invention \& Application, http://computing.derby.ac.uk/ojs/index. $\mathrm{php} / \mathrm{da} /$ article/view/22.

Hendar, K., Awalya., \&Sunawan, S. (2019). Solution-focused Brief Therapy Group Counseling to Increase Academic Resilience and SelfEfficacy. JurnalBimbinganKonseling, 8(3) , 1-7. Doi: org/10.15294 /jubk. v9i1.28494

Issa, T., \& Isaias, P. (2016). "Internet Factors Influencing Generations $\mathrm{Y}$ and $\mathrm{Z}$ in Australia and Portugal: A practical study". Information Processing and Management, 52(4), 592-617. Doi: 10.1016/j.ipm.2015.12.006

Kabat-Zinn, J., (2006). Coming to Our Senses: Healing Ourselves and The World Through Mindfulness. New York, NY: Hyerior.

Kar, P. C., Shian-Ling, K., \& Chong, C. K. (2014). Mindful-STOP: Mindfulness Made Easy for Stress Reduction in Medical Students. Education in Medicine Journal, 6(2), 48-56. Doi: 10.5959/eimj. v6i2.230

Kim, D., \& Shin, J. I. (2016). The Impacts of Smartphone Addiction and Technostress on Customer Satisfaction and Loyalty. International Journal of Security and Its Applications". 10(12), 409-418. Doi: org/10.14257/Ijsia.2016.10.12.34.

Lee, Y. K., Chang., Y Lin, Z-H Cheng (2014). The Dark Side of Smartphone Usage: Psychological Traits, Compulsive Behaviour and Technostress. Computers in Human Behavior, 31: 373 -383. Doi: org/10.1016/j.chb.2013.10.047.

Leland, M. (2015). Mindfulness and student success. Journal of Adult Education, 44(1): 19-24. Doi: EJ1072925.

Malinowski, P. (2015). "Neural Mechanisms of Attentional Control in Mindfulness Meditation. Frontiers in Neuroscience, 7, 8. Doi:10.3389/fnins.2013.00008. 
Mulawarman (2014). Brief Counseling in Schools: A Solution Focused Brief Counseling Approach for School Counselor in Indonesia. Journal of Education and Practice, 5(21): 68-72. https://www.researchgate.net/publicatio $\mathrm{n} / 312991742$.

Mulawarman (2019). PsikologiKonseling. SebuahPengantarBagiKonselor

Pendidikan. Semarang: Prenada Media Group.

Myrick, Robert D. (2011). Developmental Guidance and Counseling: A Practical Approach Fifth edition. Minneapolis: Educational Media Corporation.

Nisak, I. A. (2020). Pengaruh technostress terhadapkepuasankerjadengankonflikpekerjaa n-keluarga dan konflikkeluargapekerjaansebagaivariabel intervening di PDAM Kota Malang (Doctoral dissertation, Universitas Islam Negeri Maulana Malik Ibrahim).

Nurhaeda, N., Sutoyo, A., \& Mulawarman, M. (2019) Mindfulness Training with Deepbreathing Techniques to Increase Disability Resilience. Doi: 10.4108/eai.29-6-2019.2290355.

Ozkan, M., \& Solmaz, B. (2015). The Changing Face of The Employees-Generation Z and Their Perceptions of Work (A Study Applied to University Students). Procedia Economics and Finance, 26, 476-483. Doi: 10.1016/S2212-5671(15)00876-X.

Pflugner, K., \& Maier, C. (2019). Mitigating Technostress: An Empirical Study of Mindfulness and Techno-Stressors, 1 (2), 267-276. Doi: 10.2495/TDI-V1-N2-267276

Prakash, R. S., Hussain, M. A., \& Schirda, B., 2015. The Role of Emotion Regulation and Cognitive Control in The Association Between Mindfulness Disposition and Stress. Psychology and Aging, 30(1), 160 -171. Doi:10.1037/a0038544.

Rusandi, M. A., Sugiharto, D. Y. P., \&Sunawan, S. (2019). Effectiveness of Solution-Focused Group Counseling to Improve Planned Happenstance Skills of
Student. JurnalKonseling Dan

Pendidikan, 7(1), 30-34. Doi: 10.29210/127600.

Shakarami, M., Davarniya, R., \& Zahrakar, K. (2014). A Study of Effectiveness Of Solution-Focused Brief Therapy (SFBT) On Reducing Marital Stress In Women. https://www.sid.ir/en/journal/ViewPap er.aspx?id=420247.

Schmit, E. L., Schmit, M. K., \& Lenz, A. S. (2016). Meta-analysis of solution-focused brief therapy for treating symptoms of internalizing disorders. Counseling Outcome Research and Evaluation, 7(1), 21-39. Doi: 10.1177/2150137816660584

Susanti, P. D., Wibowo, Mungin Eddy \&Mulawarman, M. (2019). The Effectiveness of Acceptance and Commitment Therapy Counseling and Mindfulness-based Cognitive Counseling to Reduce School Burnout. JurnalBimbinganKonseling,9 (2), 173-178. Doi.org/10.15294.

Shu, Q., Tu, Q., \& Wang, K. (2011). The Impact of Computer Self-Efficacy and Technology Dependence on ComputerRelated Technostress: A Social Cognitive Theory Perspective. International Journal of Human-Computer Interaction, 27 (10), 923939.

Doi:

10.1080/10447318.2011.555313.

Tarafdar, M., Tu, Q., Ragu-Nathan, T.S., \& Ragu-Nathan, B. S. (2007). The Impact of Technostress on Role Stress and Productivity. Journal of Management Information Systems, 24(1): 301 - 328. Doi 10.2753/MIS0742-1222240109 